\title{
PROFESOR JAN SZCZEPAŃSKI W ŁODZI I JEGO BADANIA
}

W swoim artykule ograniczyłam się do pierwszego, łódzkiego okresu pracy naukowej Profesora Jana Szczepańskiego.

Profesor Szczepański, uczeń Floriana Znanieckiego, przedwojenny i powojenny współpracownik Józefa Chałasińskiego, współtwórca łódzkiego ośrodka socjologicznego, miał bardzo rozległe zainteresowania humanistyczne i filozoficzne. Zaraz po zakończeniu wojny zaczął pracować w nowo powstałym Uniwersytecie Łódzkim. Od początku bardzo interesował się metodami badań socjologicznych i metodologią.

W roku 1949/1950 zlikwidowano w polskich uniwersytetach socjologię. Powstał nowy kierunek - nauki społeczne - na którym było wiele wykładów i zajęć z różnych dziedzin, przy czym niektóre z nich miały charakter również ideologiczny. W Łodzi, mimo przepełnionego programu, udało się Józefowi Chałasińskiemu i Janowi Szczepańskiemu wprowadzić kilka wykładów i seminariów z zakresu socjologii. Jan Szczepański w latach 50. miał wykład pt. Technika opisu życia społecznego $i$ badań terenowych oraz (razem z asystentami Janem Lutyńskim i Wacławem Piotrowskim) prowadził bardzo interesujące seminarium. Napisał też pierwszy w Polsce po wojnie podręcznik pt. Techniki badań społecznych, który w $1951 \mathrm{r}$. mógł być wydrukowany tylko na papierze powielaczowym jako skrypt i bez przypisów. Mimo to służył długie lata dydaktyce uniwersyteckiej i to nie tylko w Łodzi.

W skrypcie tym autor jeszcze stosunkowo mało miejsca poświęcił tzw. technikom ankietowym, natomiast bardzo dużo obserwacji i innym badaniom jakościowym. Warto podkreślić, że metoda dokumentów osobistych, mimo że w tamtych latach została oficjalnie potępiona - w tym podręczniku była przedstawiona bez marksistowskiej krytyki. (Można przypomnieć, że w 1951 r. 
Józef Chałasiński skrytykował Młode pokolenie chtopów oraz metodologię i teoretyczne założenia swego mistrza Floriana Znanieckiego, określając je jako „idealistyczne”). Autor skryptu, zwłaszcza przy omawianiu standaryzowanych technik, choć nie mógł tego otwarcie napisać, opierał się na podręcznikach amerykańskich. Techniki badań Jan Szczepański traktował jako „społecznie neutralne", za co został ostro skrytykowany przez Adama Schaffa na konferencji informacyjnej socjologów i historyków myśli społecznej w 1952 r.

W 10 lat później Profesor w książce Socjologia. Rozwój problematyki $i$ metod (1961) wprawdzie musiał przedstawić „problematykę socjologii marksistowskiej”, ale w części poświęconej metodom i analizie materiałów już otwarcie powoływał się na literaturę zachodnią. Wyraźnie też pisał o wielkiej roli wywiadu i technik ankietowych we współczesnej socjologii.

W latach 50. ukazało się również szereg Jego znaczących artykułów z zakresu metodologii (publikowanych w „Przeglądzie Socjologicznym”, „Myśli Współczesnej”, „Więzi” i innych). Wśród nich trzeba wyróżnić studium pt. Zagadnienia metodologii badań spotecznych $w$ niektórych pracach Marksa i Engelsa („Myśl Filozoficzna” 1953, nr 2). Artykuł ten bowiem odegrał poważną rolę w dyskusjach nad empirycznymi badaniami socjologicznymi w Związku Radzieckim i w całym „obozie socjalistycznym”, co w rezultacie umożliwiło prowadzenie tych badań w krajach tzw. demokracji ludowej.

W drugiej połowie lat 50. ubiegłego wieku po śmierci Stalina również w Polsce sytuacja polityczna ogromnie zmieniła się na lepsze. Dla osób z mego pokolenia i starszych takie wydarzenia, jak XX Zjazd Komunistycznej Partii w Związku Radzieckim, referat Chruszczowa, ,polski październik” i wszystkie zmiany, które były ich następstwem, cała „odwilż”, były szokiem trudnym do wyobrażenia dla ludzi XXI w. Na uniwersytety powróciła socjologia. Powstawały nowe inicjatywy naukowe, społeczne i kulturalne. Niezwykle ważną rolę odgrywało wówczas pismo „Po prostu” założone przez młodych absolwentów po studiach, które walczyło z różnymi przejawami stalinizmu (Jan Szczepański w ramach „Biblioteczki Po prostu" opublikował tomik pt. Inteligencja $i$ społeczeństwo, 1957.)

W roku 1956 Profesor Szczepański wraz z kilkoma swoimi uczniami i współpracownikami oraz z redakcją „Po prostu” ogłosił konkurs skierowany „Do inteligencji na opis życia, dążeń i doświadczeń inteligenta”. W odezwie konkursowej na pierwszej stronie figurowało tylko „Po prostu”, ale Profesor był przewodniczącym jury, które oceniało nadesłane prace i przyznawało nagrody. (Do jury weszli członkowie redakcji i socjologowie z Łodzi: zapraszaliśmy także niektórych znanych a „nieskompromitowanych” literatów jak Marię Dąbrowską czy Jerzego Andrzejewskiego, ale niestety odmówili). Wśród organizatorów konkursu jedynie Jan Szczepański miał do czynienia z metodą biograficzną, 
ponieważ w latach 1937-1939 brał udział w opracowywaniu pamiętników młodzieży wiejskiej, z których to materiałów powstało Młode pokolenie chłopów Józefa Chałasińskiego. (W roku 1961 ukazał się najpierw w języku niemieckim ważny artykuł Jana Szczepańskiego Metoda biograficzna, znany i ceniony do dzisiaj). Zespół przygotował bardzo starannie odezwę konkursową, nie licząc specjalnie na to, że wiele osób zastraszonych życiem w stalinizmie zechce na nią odpowiedzieć. Niespodzianka była więc ogromna, ponieważ na konkurs nadesłano aż 745 prac, w większości bardzo obszernych. Stało się to możliwe jedynie dzięki „odwilży” i burzliwym przemianom w pierwszym okresie ,polskiego października". Wśród pamiętnikarzy byli potępieni i szykanowani w okresie stalinizmu dawni żołnierze AK, byli ziemianie, ale także rozczarowani komuniści, a nawet ubecy. Odezwali się chłopi, robotnicy, inteligenci, ludzie w różnym wieku. Jak napisał jeden z nich: ,konkurs ten stworzył nieskrępowaną możliwość ujawnienia przeżyć, pragnień, nadziei i sądów przeżywanych przez przeciętną jednostkę inteligencką w naszych warunkach" (Lutyńska, Piotrowski 1957). Konkurs ten trafił na moment, kiedy pod wpływem ogólnego uniesienia ludzie „odblokowali się” i szczerze opisywali swoje nieraz bardzo tragiczne losy wojenne i powojenne, pisali nawet o represjach, jakich doznali od komunistów i o swoim stosunku do Związku Radzieckiego.

Niestety, zebrane unikalne materiały - nawet ich część - nigdy nie zostały opublikowane. Wkrótce zmieniła się sytuacja polityczna i nie pozwoliła na to cenzura. (Jedyne drukowane ślady o tym konkursie to sprawozdanie K. Lutyńskiej w „Przeglądzie Socjologicznym” w 1958 r., t. XII i artykulik w łódzkiej „Kronice” autorstwa K. Lutyńskiej i W. Piotrowskiego w 1957 r., nr 14. Niektóre pamiętniki były wykorzystane w książce K. Lutyńskiej o urzędnikach z 1966 r.). Wszystkie pamiętniki zostały rozproszone i niestety zaginęły.

Konkurs na pamiętniki inteligentów z 1956 r. był swego rodzaju nawiązaniem, ukłonem w stronę przedwojennej polskiej socjologii i metodologii, dawnego mistrza Jana Szczepańskiego z Poznania - Floriana Znanieckiego oraz Józefa Chałasińskiego, u którego pracował też w Państwowym Instytucie Kultury Wsi w Warszawie. Profesor Szczepański znał ówczesną zachodnią literaturę i wiedział, że jeśli chodzi o metody, to przyszłość należy do badań ilościowych. Doszedł do przekonania, że okres „odwilży” jest najlepszą porą do ich rozpoczęcia $\mathrm{w}$ Polsce. Równolegle $\mathrm{z}$ konkursem zainicjował więc $\mathrm{w}$ Łodzi również „badania ankietowe”.

Jednak żeby prowadzić takie badania, trzeba było nauczyć się od podstaw, jak je robić. Można więc powiedzieć, że wielką zasługą Jana Szczepańskiego było sprowadzenie do Polski w drugiej połowie lat 50. metody nazwanej „ankietową" i nauczenie jej młodych socjologów z Łodzi i z Warszawy. W tym 
okresie dla Profesora oraz jego współpracowników i uczniów metoda ta łączyła się z poczuciem wejścia do socjologii zachodniej i z przekonaniem, iż badania te pozwolą odkryć, jak naprawdę żyją i co czują mieszkańcy Polski. Od czasu zakończenia wojny wiedza o polskim społeczeństwie oparta była bowiem - jak wiadomo - na lukrowanym, komunistycznym obrazie propagandowym. Wiele lat potem, w 1991 r., A. Pawełczyńska w Posłowiu do Studentów Warszawy sformułowała to w następujący sposób: „Naszym celem było kruszyć stalinizm przy pomocy socjologii. Chcieliśmy ujawnić prawdę przed społeczeństwem i ujawnić przed rządzącymi, co myśli społeczeństwo" (Grabowska, Sułek 1992: 15).

Kiedy Jan Szczepański i jego zespół w latach 50. rozpoczął w Łodzi badania, skupieni byliśmy przede wszystkim na tym, aby przeprowadzać je dobrze, kompetentnie, według wskazówek podręczników zachodnich: dobrać próbę, przygotować kwestionariusz, prawidłowo budować pytania, wyszkolić ankieterów, a potem zebrane materiały - opracować statystycznie. Można więc powiedzieć, że skoncentrowani byliśmy na sprawach tzw. technicznych. Nie mieliśmy podręczników zagranicznych, nie mówiąc już o komputerach: kodowaliśmy i liczyliśmy sami na tzw. piechotę (lub jeździło się do Warszawy do GUS-u), pisaliśmy „waląc” w klawisze zwykłych maszyn do pisania. Jedynie Profesor Szczepański miał „kapitalistyczne” metodologiczne książki, uczył z nich swoich uczniów z Łodzi i wkrótce także z Warszawy (ponieważ już od 1955 r. pracował równocześnie w IFiS PAN - w Zakładzie Podstawowych Badań Socjologicznych). Jednocześnie przekazywał nam swoje własne przemyślenia. Pamiętam niektóre jego „przykazania” kierowane do nas, jak zawsze z uśmiechem, np.: „umiejętność stawiania pytań jest podstawową cechą każdego badacza”, ,ankietę (kwestionariusz do wywiadu) trzeba poprawiać nawet 16 razy, ale poprawiona po raz 17-ty będzie z pewnością gorsza od pierwszej wersji”, ,na każdym kroku i na każdym miejscu socjolog musi obserwować". Pamiętam też, że polecił nam wszystkim pójść na amerykański film pt. Dziesięciu gniewnych ludzi, przeczytać Sanchez i jego dzieci Oskara Lewisa oraz niektóre książki z literatury pięknej.

Już wówczas Profesor Szczepański i jego zespół zdawali sobie sprawę, że w komunistycznej Polsce respondenci bardzo często nie zechcą brać udziału w badaniach lub odpowiadać na pewne pytania. Słowo „socjologiczne" nie mogło być używane, ponieważ było utożsamiane ze słowem „socjalistyczne”. Pierwsi ankieterzy byli równie przejęci jak pierwsi respondenci, którzy wpuszczali ich do domów z wielką nieufnością. W związku z taką atmosferą postanowiono, że pierwsze badania dotyczące absolwentów UŁ będą częściowo przeprowadzone za pomocą ankiety pocztowej, ponieważ wydawało się, że będzie dla badanych mniej stresujące. Jan Szczepański każdy egzemplarz ankiety podpisywał własnoręcznie (!), ponieważ liczyliśmy, że znane nazwisko 
bezpartyjnego profesora przekona ludzi do jej wypełnienia. (Jan Szczepański był wówczas w Łodzi bardzo popularny - mógł na to mieć wpływ jego udział, wraz z Józefem Chałasińskim, w procesie w Poznaniu w 1955 r., gdzie występował jako ekspert i bronił robotników, a w 1957 r. został wybrany jako bezpartyjny posłem do Sejmu (1957-1960)). Ten metodologiczny manewr udał się, ponieważ w badaniach nad absolwentami UŁ otrzymano „tylko" 50\% zwrotów ankiet pocztowych, co na tamte lata było znakomitym wynikiem.

Jan Szczepański w okresie październikowym, za pomocą ankiet pocztowych, wywiadów i innych technik, rozpoczął szeroko zakrojone badania terenowe nad klasą robotniczą, pracownikami umysłowymi i inteligencją w Polsce Ludowej. Pierwszymi z nich, prowadzonymi w latach 1955-1956, były badania „nad losami społeczno-zawodowymi absolwentów różnych kierunków Uniwersytetu Łódzkiego, technikum dla robotników i maturzystów”. Ich rezultaty ukazały się pod wspólnym tytułem Wykształcenie a pozycja społeczna inteligencji w Łodzi w 1959 i 1960 r. Jeszcze wcześniej - w 1958 r. ukazał się tom pt. Z badań klasy robotniczej $i$ inteligencji. Te trzy pierwsze książki były pracami zbiorowymi pod redakcją Jana Szczepańskiego i stanowiły początek 28-tomowej serii, zwanej potem „białą” (od koloru okładek). Niektóre książki tej serii były - jak trzy pierwsze - pracami zbiorowymi, inne samodzielnymi monografiami (często ze wstępem J. Szczepańskiego) różnych kategorii zawodowych pracowników umysłowych (jak nauczycieli, lekarzy, farmaceutów, inżynierów chemików, urzędników, dziennikarzy i innych), jeszcze inne - opracowaniami wybranych instytucji, zakładów produkcyjnych lub zagadnień, jak np. jednej z łódzkich szkół średnich, Kursów Przygotowawczych dla Robotników, Fabryki Samochodów Osobowych na Żeraniu, Fabryki Motocykli i wiele innych. Autorami byli uczniowie i doktoranci profesora oraz jego współpracownicy z Łodzi i z Warszawy. (Przykładowo podaję niektóre nazwiska autorów z Łodzi: Andrzej Borucki, Stefania Dzięcielska, Salomea i Zdzisław Kowalewscy, Jolanta Kulpińska, Krystyna Lutyńska, Władysława Milczarek, Jan Woskowski i inni). Wychodziły najpierw w Łodzi, a później już w Warszawie, wydawane kolejno przez Państwowe Wydawnictwo Naukowe, Wydawnictwo IFiS PAN, Ossolineum od roku 1958 do końca lat 60.

Rezultaty tych badań zawarte są również w szeregu własnych rozpraw syntetyzujących Jana Szczepańskiego, jak Zmiany $w$ strukturze klasowej społeczeństwa polskiego, Przemiany społeczne w Polsce Ludowej (Warszawa 1965) czy też Polish Society (New York 1970).

Prowadzenie badań socjologicznych w drugiej połowie lat 50. i potem 60 . odbywało się w określonych warunkach polityczno-historycznych. Socjologowie byli pilnowani prawie na każdym kroku, żeby nie wykroczyli poza określone 
granice wyznaczone przez komunistyczną partię. „Kto milczy, ten popiera istniejący stan rzeczy, kto nie opowiada się za postępem, ten jest obiektywnie przeciw nam" - pisał Adam Schaff w artykule Walka klas w nauce (Spodenkiewicz 2010: 30). Od czasu do czasu były organizowane konferencje z udziałem partyjnych i bezpartyjnych socjologów i filozofów, na których ich (mówiąc współczesnym językiem) „ustawiano”. Wspominałam już o „konferencji informacyjnej” w 1952 r., na której Adam Schaff, ówczesny przywódca „frontu ideologicznego", skrytykował podręcznik Jana Szczepańskiego. W 1951 r. odbyła się konferencja poświęcona badaniom terenowym (brali w niej udział Józef Chałasiński, Stanisław Ossowski i Jan Szczepański), w czasie której wyrażono pogląd, że ,jeśli jakaś ekipa znajdzie w terenie fakty niepożądane, to oznacza, że jej stosunek do Polski Ludowej jest wrogi lub przynajmniej niewłaściwy" (Ossowski 1956). Takie stwierdzenie bardzo utrudniło np. badania terenowe w spółdzielni produkcyjnej Jackowice, które Profesor Szczepański zorganizował w lecie 1951 r. dla studentów nauk społecznych UŁ. Mogli na nie pojechać tylko najbardziej pewni ideologicznie ZMP-owcy. Przed każdymi badaniami terenowymi trzeba było uzyskać zgodę od odpowiednich władz, a już najgorzej było, kiedy chciało się badać dany problem w jakiejś fabryce czy instytucji. Nieraz bardzo długo trwało, zanim uzyskało się takie pozwolenie, często dzięki pomocy partyjnych kolegów, którzy mieli lepszy dostęp do ówczesnych działaczy piastujących wysokie funkcje, takich jak np. kiedyś w Łodzi Michalina Tatarkówna.

W momencie, kiedy pokonało się te wszystkie trudności, materiały zostały zebrane i opracowane, a praca gotowa do druku - rozpoczynała się walka z cenzurą, która wykreślała zdania, strony lub w ogóle nie dopuszczała do publikacji danego artykułu lub książki. Naczelny redaktor „Przeglądu Socjologicznego” profesor Chałasiński - w takich skrajnych przypadkach ogromnie się denerwował i często wolał wycofać dany artykuł niż prosić jego autora o ,poprawki” według wskazań cenzora. Profesor Szczepański był dyplomatą i zawsze próbował „,coś utargować". Mając wrodzony wdzięk i powodzenie u pań, a ponieważ w cenzurze często pracowały towarzyszki w średnim wieku, Jan Szczepański sam biegał z maszynopisami do siedziby tej znienawidzonej przez socjologów instytucji i próbował je ,,czarować”. Nie było to łatwe. Pamiętam np. jak to było z pierwszymi tomami „białej serii” (opublikowane w 1958, 1959). Cenzorka, z którą rozmawiał profesor, twierdziła, że nie jest możliwe, aby studenci ,socjalistycznego uniwersytetu" mogli pozytywnie oceniać przedwojennych profesorów, a krytycznie wyrażać się o szkoleniach organizowanych przez partię lub ZMP, że nie chcą uczyć się rosyjskiego - języka największego przyjaciela Polski itd. itd. Uważała, 
że ona wie lepiej niż cytowani respondenci i autorzy opracowań. Nie udało się jej przekonać. Tomy ukazały się okaleczone przez cenzurę. Podałam tylko maleńki przykład, ale to była codzienność - z pewnością niezrozumiała obecnie - nie tylko Profesora Szczepańskiego, ale wszystkich autorów i redaktorów w całej Polsce Ludowej.

Książki Jana Szczepańskiego oparte na badaniach ilościowych stały się znane i spotkały się z uznaniem w kraju i za granicą. W Polsce były jednak także krytykowane m.in. za „płaski empiryzm”. Nieco później, w latach 60. Adam Schaff zainicjował słynną wówczas dyskusję o ,ankietomanii”. Toczyła się ona na łamach pism społeczno-kulturalnych i zabrało w niej głos kilkanaście osób. Jan Szczepański wziął w niej także udział i opublikował w „Polityce” (1963, nr 23) artykuł pt. $O$ ankietach, ankietomanii $i$ kretynizmie matematycznym. Pokazał w nim, na czym polega „metoda ankietowa” i bronił jej. Profesor, propagując i broniąc w Polsce Ludowej badań ilościowych, nigdy nie był w stosunku do nich bezkrytyczny. Wychowany w tradycji socjologii humanistycznej, doskonały znawca historii myśli społecznej, widział ich wszystkie niedoskonałości i mankamenty. Uświadamiał je również swoim uczniom i współpracownikom, co, według mnie, mogło też mieć wpływ na powstanie w latach 60. tzw. łódzkiej szkoły metodologicznej (Zygmunt Gostkowski, Jan Lutyński). Kiedy w roku 1966 wychodził tom I Analiz i prób technik badawczych w socjologii pod redakcją Zygmunta Gostkowskiego, Jan Szczepański napisał do niego wstęp. Powołał się w nim na Kurs filozofii pozytywnej Augusta Comte'a, który 130 lat temu stawiał sobie pytania o „ważność i pewność poznania socjologicznego" i „deformację procesu poznawania” (Gostkowski 1966: 5).

Niedawno jedna z moich młodych koleżanek, można powiedzieć z pokolenia socjologicznych wnuków czy nawet prawnuków Jana Szczepańskiego, zapytała mnie, czy Profesora można nazwać „metodologiem”. Chyba nie w tym sensie, w jakim nazywamy metodologami np. Stefana Nowaka, Zygmunta Gostkowskiego czy Jana Lutyńskiego - miał on bardzo szerokie zainteresowania i osiągnięcia także w różnych innych dziedzinach socjologii. Ale znaczenie Profesora Szczepańskiego w tym zakresie polegało na czymś innym. Łódzki socjolog w latach 50., w komunistycznej Polsce, zaczął prowadzić badania terenowe, sprowadził z kapitalistycznego Zachodu „burżuazyjne” metody ilościowe. W przemówieniu wygłoszonym w 1973 r. z okazji nadania Profesorowi doktoratu honoris causa UŁ, Jan Lutyński powiedział: „Nikt nie zrobił więcej w Polsce od Profesora Szczepańskiego dla spopularyzowania socjologii i jej badań oraz dla wykazania ich dużej roli we współczesnym (ówczesnym) społeczeństwie" (Lutyński 1985: 13). I choć od tego czasu minęło już wiele lat i nie umniejszając w tym zakresie zasług innych wybitnych socjologów prowadzących w okresie PRL-u badania empiryczne - wydaje się, że z tym stwierdzeniem można zgodzić się i obecnie. 


\section{Bibliografia}

Gostkowski Z. (1966), Analizy i próby technik badawczych w socjologii, t. I, Ossolineum, Wrocław.

Grabowska M., Sułek A. (1992), Stefan Nowak jako badacz społeczeństwa polskiego, [w:] M. Grabowska, A. Sułek (red.), Dziedzictwo Stefana Nowaka, ISUW, Warszawa.

Lutyńska K., Piotrowski W. (1957), Prawda o życiu i dążeniach naszej inteligencji, „Kronika”, nr 14.

Lutyński J. (1985), Przemówienie z okazji doktoratu honoris causa w Uniwersytecie Łódzkim, [w:] J. Kulpińska (red.), Społeczeństwo i socjologia. Księga poświęcona Janowi Szczepańskiemu, Ossolineum, Wrocław.

Ossowski S. (1993), Taktyka i kultura, „Przegląd Kulturalny” 1956, nr 13, cyt. za J. Lutyński, Orientacje metodologiczne w tódzkim ośrodku socjologicznym, „Przegląd Socjologiczny”, t. XL.

Spodenkiewicz P. (2010), Lokatorzy hotelu Cracovia. Inwigilacja uczestników V Zjazdu Socjologicznego w 1977, [w:] P. Franaszek, Sttamszona nauka?, IPN, Warszawa. 